\title{
Primary immunoglobulin deficiency and haematological disorders
}

\author{
M. A. H. FRENCH* \\ M.B., Ch.B., M.R.C.P., F.R.A.C.P. \\ R. L. DAWKINS \\ M.D., M.R.C.P., F.R.A.C.P., F.R.C.P.A. \\ J. M. JACKSON \\ B.Sc, M.B., Ch.B., F.R.A.C.P., F.R.C.P.A.
}

Departments of Clinical Immunology and Haematology, Royal Perth Hospital, Perth, Western Australia

Summary

Nine patients with immunoglobulin deficiency and various haematological disorders are presented. In all patients, recurrent infections had antedated the onset of the haematological disorder but, in most, the possibility of primary immunodeficiency had not been considered until after the haematological diagnosis had been established. The recognition of immunodeficiency is important since such patients may require steroids, immunosuppressive therapy or splenectomy. Gammaglobulin would appear to be the appropriate therapy in this situation. Infections were reduced in all 6 patients so treated.

KEY WORDS: immunodeficiency, haematological disease, auto-immunity.

\section{Introduction}

Low serum immunoglobulin concentrations may occur in a variety of haematological disorders, but the significance of this finding is not always recognised. In non-Hodgkin's lymphoma and chronic lymphocytic leukaemia, immunodeficiency is believed to be secondary in most cases. In other disorders, however, immunodeficiency may be a pathogenetic factor. Patients with late onset hypogammaglobulinaemia or $\operatorname{IgA}$ deficiency have an increased frequency of auto-immune disease, including haematological disorders such as auto-immune haemolytic anaemia (AIHA), idiopathic thrombocytopaenic purpura (ITP) and pernicious anaemia (PA) (Asherson and Webster, 1980). Conversely, patients with AIHA have a high prevalence of low serum immunoglobulin concentrations (Blajchman et al.,

\footnotetext{
* Present address: Department of Medicine, Clinical Sciences Centre, Northern General Hospital, Sheffield.

Correspondence: Professor R. Dawkins, Department of Clinical Immunology, Royal Perth Hospital, Box X2212, G.P.O. Perth, Western Australia 6001.
}

1969). We have been impressed by the benefit whict? can be obtained by careful assessment and managee ment of the immune defect in some patients, particu larly those in whom there is a history of abnorma susceptibility to infection.

We describe a group of patients with haematological disease and immunoglobulin deficiency, all of whom had recurrent infections before the onset of the haematological disease. Gammaglobulin therapy wast effective in all 6 patients treated.

The recognition and treatment of immunoglobuin deficiency is particularly important in such patiềi. since steroids, immunosuppressive therapy and sple nectomy may exacerbate the predisposition to infece tion.

Materials and methods

Patients

All 9 patients were seen by the Department of Haematology and selected by virtue of either: (1) the development of haematological disorders complicating recognised immunodeficiency or; (2) the presence of immunoglobulin deficiency and symptomatic im? munodeficiency in patients with haematological diş orders.

At the time of investigation none of the patients was receiving steroid, immunosuppressive or gammat globulin therapy.

\section{Methods}

Serum immunoglobulins were measured by radiẩ immunodiffusion (Oxford). Antinuclear antibodies (ANA), smooth muscle antibodies (ASM), mitochom drial antibodies (AMC), parietal cell antibodies (APC) and thyroid microsomal antibodies (ATM) were measured by indirect immunofluorescence (Hawkins et al., 1979) and thyroglobulin antibodie (ATG) by passive haemagglutination (Thymune, $\mathbb{T}$ 
Burroughs-Wellcome). Cold reactive lymphocytotoxic antibodies (LCA) were measured by a complement-dependent cytotoxicity method (Zilko et al., 1979). In one patient, anti-IgA antibodies were demonstrated by Dr J. V. Wells of the Kolling Institute, Royal North Shore Hospital, New South Wales. Routine haematological methods described by Dacie and Lewis (1975) were used.

Six of the 9 patients underwent additional immunological assessment. The methods used for immune function testing and criteria for symptomatic immunodeficiency will be given elsewhere (French et al.).

\section{Results}

The clinical and laboratory findings in the 9 patients are summarised in Tables 1 and 2 . The cases were composed of 4 cases of AIHA, one of chronic idiopathic neutropaenia, one of ITP, 2 of PA and one of non-Hodgkin's lymphoma.

\section{Autoimmune haemolytic anaemia}

Warm reactive IgG erythrocyte autoantibodies were present in 3 of the 4 patients with AIHA. Cold reactive IgM erythrocyte autoantibodies were demonstrated repeatedly over a 15 -year period in patient no. 4. Although the highest titre of serum cold agglutinins only reached a maximum of $1 / 256$, it was shown on several occasions that the direct Coombs' test was only positive at $4^{\circ} \mathrm{C}$ and that the indirect Coombs' test became negative following absorption

TABLE 1. Clinical details

\begin{tabular}{|c|c|c|c|c|c|c|c|}
\hline Patient & Sex & Age & $\begin{array}{l}\text { Haematological } \\
\text { disorder }\end{array}$ & $\begin{array}{l}\text { History of antecedent } \\
\text { infections }\end{array}$ & $\begin{array}{l}\text { Other features of primary } \\
\text { immunoglobulin deficiency }\end{array}$ & Splenectomy & $\begin{array}{c}\text { Gammaglobulin } \\
\text { therapy }\end{array}$ \\
\hline 1 & $\mathbf{F}$ & 23 & AIHA & $\begin{array}{l}\text { Recurrent bronchitis, sinusitis } \\
\text { and otitis media }\end{array}$ & - & + & + \\
\hline 2 & $\mathbf{F}$ & 66 & AIHA & Recurrent respiratory infections & Asthma, allergic rhinitis & & + \\
\hline 3 & $\mathbf{F}$ & 37 & AIHA & $\begin{array}{l}\text { Recurrent respiratory infections. } \\
\text { Bronchiectasis }\end{array}$ & $\begin{array}{l}\text { Systemic lupus erythematosus. } \\
\text { Hypothyroidism }\end{array}$ & & \\
\hline 4 & $\mathbf{F}$ & 73 & AIHA & Recurrent bronchitis & Epilepsy & & \\
\hline 5 & $\mathbf{F}$ & 56 & $\begin{array}{l}\text { Chronic idiopathic } \\
\text { neutropaenia }\end{array}$ & $\begin{array}{l}\text { Recurrent respiratory infections. } \\
\text { Bronchiectasis }\end{array}$ & - & + & + \\
\hline 6 & $\mathbf{M}$ & 33 & ITP & Recurrent skin furunculosis & - & + & \\
\hline 7 & $\mathbf{M}$ & 70 & PA & $\begin{array}{l}\text { Recurrent bronchitis and } \\
\text { sinusitis }\end{array}$ & Coeliac disease, giardiasis & & + \\
\hline 8 & $\mathbf{F}$ & 38 & PA & Chronic sinusitis & $\begin{array}{l}\text { Coeliac disease, } \\
\text { bronchial carcinoma }\end{array}$ & & + \\
\hline 9 & $\mathbf{F}$ & 34 & Lymphocytic lymphoma & $\begin{array}{l}\text { Recurrent bronchitis and } \\
\text { sinusitis }\end{array}$ & - & + & + \\
\hline
\end{tabular}

AIHA = autoimmune haemolytic anaemia; ITP=idiopathic thrombcytopenic purpura; $P A=$ pernicious anaemia.

TABLE 2. Laboratory findings

\begin{tabular}{|c|c|c|c|c|c|c|c|c|c|c|}
\hline \multirow[b]{2}{*}{ Patient } & \multicolumn{3}{|c|}{$\begin{array}{c}\text { Serum } \\
\text { immunoglobulins }(\mathrm{g} / \mathrm{l})\end{array}$} & \multicolumn{7}{|c|}{ Autoantibodies } \\
\hline & IgG & IgM & IgA & ANA & ASM & AMC & APC & ATM & ATG & LCA \\
\hline 1 & $4 \cdot 7$ & $1 \cdot 7$ & 0.04 & - & - & - & - & - & - & - \\
\hline 2 & $7 \cdot 4$ & $5 \cdot 6$ & 0.24 & + & + & - & - & + & - & + \\
\hline 3 & $13 \cdot 6$ & 0.1 & $0 \cdot 3$ & + & - & - & - & + & + & + \\
\hline 4 & 6.8 & 1.0 & 0.2 & - & - & - & - & - & - & - \\
\hline 5 & 1.9 & 0.32 & 0.04 & - & - & - & - & - & - & - \\
\hline 6 & 15.0 & $3 \cdot 0$ & $0 \cdot 3$ & - & - & - & - & ND & ND & ND \\
\hline 7 & $3 \cdot 1$ & $0 \cdot 1$ & 0.04 & - & - & - & - & - & - & - \\
\hline 8 & 1.7 & $<0.1$ & 0.04 & - & - & - & - & - & - & - \\
\hline 9 & $2 \cdot 2$ & 1.4 & 0.04 & - & - & - & - & - & - & ND \\
\hline
\end{tabular}


of serum cold agglutinins. The antibody showed iantigen specificity.

Haemolysis was controlled by steroids in all patients except no. 1 and this treatment continues in patients 2 and 3 . The latter patient also had systemic lupus erythematosus (SLE). Patient 4 died from unknown causes shortly after discontinuing steroid therapy. Splenectomy was eventually necessary in patient 1 , and no further therapy for AIHA has since been required.

In all 4 patients, there was an antecedent history of recurrent sino-pulmonary infections. Serum immunoglobulins were not measured until 12 years after the onset of AIHA in patient 2. In patients 3 and 4 , immunoglobulin deficiency was detected at the onset of disease. Gammaglobulin therapy was beneficial in patients 1 and 2, but was discontinued in the latter because of febrile myalgia following one of the injections. Serum antibodies to $\operatorname{IgA}$ were demonstrated at a titre of $1 / 8$.

\section{Chronic idiopathic neutropaenia}

Chronic idiopathic neutropaenia occurred in a female (no. 5) with a 26-year history of recurrent sino-pulmonary infections and bronchiectasis. A neutrophil count of $0.9 \times 10^{9} /$ litre was found following a respiratory infection. One year earlier, the count had been normal. Splenomegaly had been noted for the past 10 years. Although splenectomy resulted in a return to normal of the neutrophil count, sino-pulmonary infections became more severe. There was marked improvement following the introduction of gammaglobulin therapy.

\section{Idiopathic thrombocytopaenia}

Poor haemostasis following surgical drainage of a skin abscess was due to ITP in patient 6 . A history of recurrent skin furunculosis dating from childhood, prompted investigation for impaired humoral immunity and partial IgA deficiency was discovered. Thrombocytopaenia resolved after splenectomy. On review 6 years later, ITP was in continued remission, serum $\operatorname{IgA}$ was $0.3 \mathrm{~g} / \mathrm{litre}$, and so far he has been free of sino-pulmonary infection.

\section{Pernicious anaemia}

Pernicious anaemia in 2 patients was associated with coeliac disease and giardiasis in both. There was an antecedent history of sino-pulmonary infections in both, but in one patient, (no. 7), immunoglobulin deficiency was not considered and not found until 18 years after the diagnosis of PA. In both patients, sinopulmonary infections improved after gammaglobulin therapy, which also appeared to benefit the diarrhoea. Shortly after the commencement of gamma- globulin, a bronchial carcinoma was found in patien乞̨ 8. Interestingly, delayed hypersensitivity to recalp antigens and dinitrochlorobenzene was absent, an $q^{2}$ phytohaemagglutinin lymphocyte transformation de creased whereas they were previously normal. Deaths occurred despite chemotherapy and radiotherapy.

\section{Lymphocytic lymphoma}

In the single patient with lymphocytic lymphoma? $\operatorname{IgG}$ and IgA deficiency were found on routines investigation. Recurrent sino-pulmonary infections over many years had preceded the onset of lym $=$ phoma. Regular gammaglobulin therapy was effect tive in reducing the frequency and severity of infections during her 4 years remission which contin ues to date. In view of the fact that the patient was. splenectomised at diagnosis and had received inten 5 sive chemotherapy over a period of 15 months, the reduction in episodes of infection is notable.

\section{Immunological findings}

Various patterns of combined and isolated immunoglobulin deficiency were present (Table 2) 3 Absolute or partial IgA deficiency was present in all Serum IgG ranged from $1.9 \mathrm{~g}$ /litre to $14 \mathrm{~g}$ /litre and IgM from $0.1 \mathrm{~g} /$ litre to $5.6 \mathrm{~g} /$ litre. In the singiee patient with haemolytic anaemia and cold agglut ins. (no. 2), the serum IgM concentration varied fromo $5.6 \mathrm{~g} /$ litre to $15.6 \mathrm{~g} /$ litre over a 4 -year periød. Peripheral blood T and B cells were present in al patients. In two, (nos. 2 and 3) there was lympho: penia associated with serum lymphocytotoxic anti $\stackrel{D}{2}$ bodies.

Serum autoantibodies, other than anti-erythrocyte antibodies, were detected in only 2 patients, both of? whom had more than one autoantibody (Table 2) Definite SLE was associated with increased serumo DNA binding in one of these patients (no. 3). ParietaP. cell antibodies were not detected on repeated exami-윽 nations of sera from both patients with PA.

\section{Immune function tests}

Titres of serum E.coli antibody (normal $>1 / 8$ ) and isohaemagglutinins (normal $>1 / 8$ ) were low in 5 of theo 6 patients studied. Peak tetanus toxoid antibody titres. (normal $>1 / 160$ ) were low in 3 patients. Two of thesêr and one other has low peak Salmonella typhi HN antibodies (normal $>1 / 80$ ).

\section{Discussion}

Nine patients presenting with various haematological diseases are described, all of whom had $\stackrel{\text { s }}{+}$ antecedent recurrent infections attributable to primary immunoglobulin deficiency. In only one patient was immunoglobulin deficiency identified before the 
diagnosis of the haematological disease. The history of abnormal susceptibility to infection in all patients is interpreted as evidence for a primary immunoglobulin deficiency syndrome although most patients did not have hypogammaglobulinaemia. Some supporting evidence for an antibody deficiency syndrome is provided by the demonstration of low titres of E.coli antibodies and isohaemagglutinins and low antibody responses following immunisation in some patients. However, haematological disorders, particularly auto-immune cytopaenias are a complication of IgA deficiency (Sandler and Zlotnik, 1976) and other dysgammaglobulinaemias (Stoelinga, Van Muster and Sloof, 1969).

The interpretation of low serum immunoglobulins in patients receiving steroid or immunosuppressant therapy may be difficult and the effects of therapy may have been a factor in some of the patients described by Blajchman et al. (1969). This was not a factor in the patients described here. It is important to look for immunoglobulin deficiency before starting immunosuppressive or steroid therapy, particularly in patients with an increased susceptibility to infections.

The presence of primary immunoglobulin deficiency in patients with a variety of haematological diseases is of interest from 2 points of view. Firstly, it is possible that the underlying immunoglobulin deficiency may predispose to the haematological disorder. Secondly, the recognition of an associated immunodeficiency syndrome is important in further clinical management.

Several mechanisms whereby immunoglobulin deficiency may be implicated in the pathogenesis of autoimmune haemolytic disease have been suggested (Blajchman et al., 1969; Zueler et al., 1970; Amman and Hong, 1970). Pernicious anaemia, with or without giardiasis and coeliac disease, occurs in approximately $20 \%$ of patients with late onset hypogammaglobulinaemia (Hermans, Diaz-Buxo and Stobo, 1976). A search for immunoglobulin deficiency is, therefore, justified in PA, especially if there is a background of recurrent diarrhoea and infections. The absence of serum parietal cell antibodies is a feature of this variety of PA. Presumably, therefore, the autoantibody is not responsible for the atrophic gastritis in this and other forms of PA (Editorial, 1970).

Unlike AIHA, ITP and PA, chronic idiopathic neutropaenia is infrequently associated with primary immunoglobulin deficiency ( $\mathrm{Ng} \&$ Prankerd, 1976; Webster et al., 1981). It has been suggested that chronic idiopathic neutropaenia may be an autoimmune disease (Boxer et al., 1975) and the cases of neutropaenia associated with late onset hypogammaglobulinaemia described by Webster et al. (1981) had autoantibodies to neutrophils. It is probable, there- fore, that this is a further example of an autoimmune disease occurring with primary immunoglobulin deficiency.

Immunoglobulin deficiency in most patients with non-Hodgkin's lymphoma is secondary to the lymphoproliferative process. However, an increased incidence of lymphoproliferative disease has been reported in individuals with primary immunoglobulin deficiencies (WHO, 1979). A history of recurrent sinopulmonary infections before the onset of lymphoma in our patient suggests that the immunoglobulin deficiency was primary.

It is important to search for primary immunoglobulin deficiency in patients such as those described here. Patients with recurrent infections may be given the benefit of gammaglobulin. In the absence of symptomatic deficiency, careful follow-up is desirable. The increased susceptibility to infection due to primary immunoglobulin deficiency may be exacerbated by the use of immunosuppressants or by splenectomy (Eicher, 1979).

Finally, blood transfusion may be complicated by reactions possibly due to anti-IgA antibody (Vyas, Perkins and Fudenberg, 1968).

As illustrated by these cases, gammaglobulin therapy can be effective in partial and selective immunoglobulin deficiency as well as hypogammaglobulinaemia (Buckley, 1976; Koistinen, Heinkila and Leikola, 1978). The risk of reactions to therapy is probably not as great as once thought (Koistinen et al., 1978), and only prevented one of our 6 patients from continuing treatment.

\section{Acknowledgments}

We are grateful to the physicians who allowed us to follow these patients. We acknowledge the assistance of Dr J. V. Wells, Mr T. Cobain, Mr R. Krueger, Ms J. K. Hendriks, Ms T. Ralla and Mrs J. Leicester.

(Publication 8003 of the Departments of Clinical Immunology, Royal Perth Hospital and Queen Elizabeth II Medical Centre).

\section{References}

Amman, A.J. \& Hong, R. (1970) Selective IgA deficiency and autoimmunity. Clinical and Experimental Immunology, 7, 833.

ASherson, G.L. \& WEBSTER, A.D.B. (1980) Diagnosis and treatment of immunodeficiency diseases. Blackwell Scientific Publications, Oxford.

Blajchman, M.A., Dacie, J.V., Hobbs, J.R., Pettit, J.E. \& WorlLEDGE, S.M. (1969) Immunoglobulins in warm-type autoimmune haemolytic anaemia. Lancet, ii, 340.

BoXer, L.A., GreenberG, M.S., Boxer, G.J. \& Stossel, T.P. (1975) Autoimmune neutropaenia. New England Journal of Medicine, 293, 15, 744.

BuCKLEY, R.H. (1976) Replacement therapy for treatment of pulmonary infections. In: Immunologic and infectious reactions in the lung (Eds. C. H. Kirkpatrick and H. Y. Reynolds), p. 335. Dekker, Basel.

DACIE, J.V. \& LEWIS, S.M. (1975) Practical haematology, 5th edn. Churchill Livingstone, Edinburgh. 
EDITORIAL (1970) Immunoglobulin deficiency and pernicious anaemia. Lancet, i, 458.

EICHER, E.R. (1979) Splenic function: Normal, too much and too little. American Journal of Medicine, 66, 311.

French, M.A.H., Dawkins, R.L., Zilko, P.J., Cobain, T.C. \& DAVEY, M. The assessment of antibody deficiency: an evaluation of diagnostic methods. (Submitted).

Hawkins, B.R., O'ConNoR, K.J., DaWkins, R.L. \& Roger, B. (1979) Autoantibodies in an Australian Population 1. Prevalence and persistence. Journal of Clinical and Laboratory Immunology, $1,211$.

Hermans, P., Diaz-Buxo, J.A. \& Stobo, J.D. (1976) Idiopathic late-onset immunoglobulin deficiency. American Journal of Medicine, 61, 221.

Koistinen, J., Heinkila, M. \& Leikola, J. (1978) Gammaglobulin treatment and anti-IgA antibodies in IgA deficient patients. British Medical Journal, 2, 923.

NG, R.P. \& PRANKERD, T.A.J. (1976) IgA deficiency and neutropaenia. British Medical Journal, 1, 563.

SANDLER, S.G. \& ZlOTNIK, A. (1976) IgA deficiency and autoimmune haemolytic disease. Archives of Internal Medicine, 136, 93.
Stoelinga, G.B.A., Van Munster, P.J., Sloof, J.P. (1969) Antibody deficiency syndrome and autoimmune haemolytic anaemia in a boy with isolated IgM deficiency, dysimmunoglobulinaemia type 5. Acta paediatrica Scandinavica, 58, 352.

VYAS, G.N., PERKINS, H.A. \& FUDENBERG, H.H. (1968) Anaphylactoid transfusion reactions associated with anti IgA. Lancet, ii, 312.

Webster, A.D.B., Platts-Mills, T.A.E., JanNosy, G., Morgan, M., ASHERSON, G.L. (1981) Autoimmune blood dyscrasias in five patients with hypogammaglobulinaemia: Response of Neutropaenia to Vincristine. Journal of Clinical Immunology, 1, 113.

WHO SCIENTIFIC GROUP (Report of) (1979) Immunodeficiency Clinical Immunology and Immunopathology, 13, 296.

Zilko, P.J., DaWkins, R.L., Holmes, K. \& WITt, C. (1979) Genetic \& control of suppressor lymphocyte function in myasthenia gravis: relationship of impaired suppressor function to HLA-B8/DRW3 and cold reactive lymphocytotoxic antibodies. Clinical Immunology and Immunopathology, 14, 222.

Zueler, W., Mastrangeld, R., Stulberg, C., Poulik, M., Page, R. \& THOMPSON, R. (1970) Autoimmune haemolytic anaemia. Natural history and viralimmunologic interaction in childhood. 3 American Journal of Medicine, 49, 80.

(Accepted 27 October 1982) 